\title{
TERF1 Gene
}

National Cancer Institute

\section{Source}

National Cancer Institute. TERF1 Gene. NCI Thesaurus. Code C20563.

This gene plays a role in telomere leng th maintenance and the inhibition of telomerase activity. 